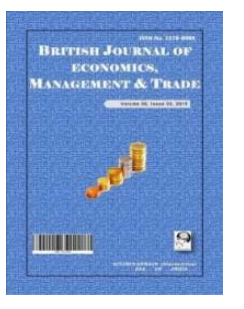

\title{
Assessment of Factors Affecting the Performance of Women Entrepreneurs in MSE in Polosara District of Ganjam, Odisha
}

\author{
Satyajit Roy ${ }^{{ }^{*}}$, Priyanka Tripathy ${ }^{1}$ and P. K. Tripathy ${ }^{2}$ \\ ${ }^{1}$ Research Scholar, Department of Management and Commerce, Ravenshaw University, \\ Cuttack, India. \\ ${ }^{2}$ Department of Statistics, Utkal University, Bhubaneswar, India.
}

\begin{abstract}
Authors' contributions
This work was carried out in collaboration between all authors. Authors SR and PT designed the study, performed the statistical analysis, wrote the protocol and wrote the first draft of the manuscript. Author PKT managed the analyses of the study and the literature searches. All authors read and approved the final manuscript.

Article Information

DOI: 10.9734/BJEMT/2017/32298

Editor(s):

(1) Cohen Yuval, The Open University of Israel, Israel.

Reviewers:

(1) Jane Omwenga, jomo kenyatta university of agriculture and technology, Kenya. (2) Gülen Özdemir, Namık Kemal University Tekirdağ, Turkey.

(3) Ma José Portillo Navarro, University of Murcia, Spain

Complete Peer review History: http://www.sciencedomain.org/review-history/19130
\end{abstract}

Original Research Article

Received $19^{\text {th }}$ February 2017 Accepted $10^{\text {th }}$ April 2017 Published $18^{\text {th }}$ May 2017

\section{ABSTRACT}

Entrepreneurship is increasingly recognized as an important driver of economic growth, productivity, innovation and employment, and it is widely accepted as a key aspect of economic dynamism. Entrepreneur is the key factor of entrepreneurship and now women have been recognized as successful entrepreneurs as they have qualities desirable and relevant for entrepreneurship development. Entrepreneurship is a more suitable profession for women than regular employment in public and private sectors since they have to fulfill dual roles. Increasingly, female entrepreneurs are considered important for economic development. Not only do they contribute to employment creation and economic growth through their increasing numbers, but they also make a contribution to the diversity of entrepreneurship in the economic process.

This study was designed to assess the factors that affect the performance of women entrepreneurs in MSEs. It also addressed the characteristics of women entrepreneurs in MSEs. A sample of 150 
women entrepreneurs was taken for the study using stratified and simple random sampling. In the process of answering the basic questions, a questionnaire that include demographic profiles, characteristics of women entrepreneurs and their enterprises and factors that affect the performance of women entrepreneurs in MSEs was designed. After the data has been collected, it was analyzed using SPSS by applying factor analysis. The results of the study indicates the personal characteristics of women entrepreneurs in MSEs and their enterprise that affect their performance. It also shows that lack of own premises (land), financial access, intense competition, inadequate access to training, access to technology and access to raw materials were the key economic factors that affect the performance of women entrepreneurs in MSEs. Based on the major findings, recommendations were forwarded to existing and potential entrepreneurs, MSEs and Micro finance agencies.

Keywords: Entrepreneur; women; MSE.

\section{INTRODUCTION}

As globalization reshapes the international economic landscape and technological change creates greater uncertainty in the world economy, the dynamism of entrepreneurship is believed to be able to help to meet the new economic, social and environmental challenges. Governments increasingly consider entrepreneurship and innovation to be the cornerstones of a competitive national economy, and in most countries entrepreneurship policies are in fact closely connected to innovation policies, with which they share many characteristics and challenges. The dynamic process of new firm creation introduces and disperses innovative products, processes and organizational structures throughout the economy.

Transforming enormous ideas into economic opportunities is the decisive issue of entrepreneurship. History shows that economic progress has been significantly advanced by pragmatic people who are entrepreneurial and innovative, able to exploit opportunities and willing to take risks. The role of entrepreneurship and an entrepreneurial culture in economic and social development has often been underestimated. Over the years, however, it has become increasingly apparent that entrepreneurship indeed contributes to economic development. Nevertheless, the significant numbers of enterprises were owned by men. In other words, it was not common to see womenowned businesses worldwide especially in developing countries like India. The idea and practice of women entrepreneurship is a recent phenomenon. Until the 1980's little was known about women entrepreneurship both in practice and research, which made its focus entirely on men. Scientific discourse about women's entrepreneurship and women owned and run organizations is just the development of 1980s. Even though we observe a number of women entrepreneurs in the business, recent studies show that most of them are found in Micro and Small Enterprises (MSEs).

Women have been taking increasing interest in recent years in income generating activities, self employment and entrepreneurship. This is seen in respect of all kinds of women both in urban and rural areas. Women are taking up both traditional activities (knitting, pickle making, toy making, jam and jelly) and also nontraditional activities (computer training, catering services, beauty parlour, gym etc.). It is clear that more and more women are coming forward to set up enterprises. In the process of entrepreneurship, women have to face various problems associated with entrepreneurship and these problems get doubled because of her dual role as a wage earner and a homemaker.

Even though entrepreneurship is not free of risks, existing and potential entrepreneurs should not see it as a last resort. This is because starting own business creates sense of independence, flexibility and freedom; make own boss, give time and financial freedoms. Besides this, in the time of globalization, it would be unthinkable to get jobs easily because of the serious competition throughout the world. Moreover, to tackle the different economic, social/cultural and legal/ administrative bottlenecks they face, women entrepreneurs should make lobbies together to the concerned government officials by forming entrepreneurs associations.

\section{LITERATURE REVIEW}

Entrepreneurship is the dynamic process of creating incremental wealth. This wealth is 
created by individuals who assume the major risks in terms of equity, time and/or career commitments of providing values for some product or service. The product or service may/may not be new or unique but value must be infused by the entrepreneur by securing and allocating the necessary skills and resources.

Ahl et al. [1] recognize that there has been a political change, influenced by neo-liberal thought, in which politicians have handed over the welfare state's responsibilities to the market and they encourage entrepreneurship, not least among women and, if possible, within STEM fields.

Opportunity identification is rapidly becoming a key focal point of research in the entrepreneurship domain. This study is the first to explore gender differences in opportunity identification. Utilizing two distinct samples (95 senior undergraduate students, 189 entrepreneurs in two high-technology industries), we found that women and men utilize their unique stocks of human capital to identify opportunities and that they use fundamentally different processes of opportunity identification. However, we did not find any difference in the innovativeness of the opportunities identified. This research contributes both to the opportunity identification literature and to theories of social feminism by showing empirically that although women and men utilize different processes to identify opportunities, neither process is inherently superior. DeTienne D. and Chandler G. [2].

The work of Green P et al. [3], examines comparatively the new and emerging roles of women entrepreneurs. It is suggested that despite the similarities among business groups, women often differ from men in their choice of industry, financing options, growth strategies, and governance structures. This paper draws on the work of other researchers who identified the differences between men and women in the challenges they face in creating and managing new and growing businesses. The authors argued that in order to develop better theoretical constructs, these differences should be considered.

Even though entrepreneurship has its own advantages, it is not free of problems. For this there are a number of factors. Samiti [4], Tan [5] classified the basic factors that affect entrepreneurs in to two broad categories economic and social.

The economic factors include competition in the market; lack of access to the market, lack of access to raw material ,lack of capital or finance, lack of marketing knowledge; lack of production/ storage space; poor infrastructure; inadequate power supply and lack of business training.

The social factors include lack of social acceptability; having limited contacts outside prejudice and class bias; society looks down upon; attitude of other employees; and relations with the work force.

Besides this, Gemechis [6], Hisrich [7,8], ILO [9] added Social and cultural attitude towards youth entrepreneurship; entrepreneurship education; administrative and regulatory framework; and business assistance and support; barriers to access technology are crucial factors that affect entrepreneurial success.

The ILO [10], report that the idea and practice of women entrepreneurship is a 1980's phenomenon. That is until the 1980's little was known about women entrepreneurship both in practice and research, which made its focus entirely on men. A variety of studies have revealed that enterprises owned by women experience the same challenges as those owned by men; however certain characteristics are typical for many women-owned firms.

Many entrepreneurs and, in particular women, tend to steer clear because of lack of information, and conditions such as high transaction costs and interest rates averaging above 35 per cent per annum" (ILO [11] p.13).

Entrepreneurship is becoming an increasingly important source of employment for women across many countries. The level of female involvement in entrepreneurial activity, however, is still significantly lower than that of men. Results show that subjective perceptual variables have a crucial influence on the entrepreneurial propensity of women and account for much of the difference in entrepreneurial activity between the sexes. Specifically, it is found that women tend to perceive themselves and the entrepreneurial environment in a less favorable light than men across all countries in the sample and regardless of entrepreneurial motivation. Results also suggest that perceptual variables 
may be significant universal factors influencing entrepreneurial behavior Langowitz et al. [12].

Women's productive activities, particularly in industry, empower them economically and enable them to contribute more to overall development. Whether they are involved in small or medium scale production activities, or in the informal or formal sectors, women's entrepreneurial activities are not only a means for economic survival but also have positive social repercussions for the women themselves and their social environment United Nations Industrial Development Organization (UNIDO [13]).

Women Entrepreneurs in MSEs are important to almost all economies in the world, but especially to those in developing countries and, within that broad category, especially to those with major employment and income distribution challenges. On what we may call the "static" front, women entrepreneurs in MSEs contribute to output and to the creation of "decent" jobs; on the dynamic front they are a nursery for the larger firms of the future, are the next (and important) step up for expanding micro enterprises, they contribute directly and often significantly to aggregate savings and investment, and they are involved in the development of appropriate technology.

In an increasingly international marketplace, many companies are finding that prosperity is best achieved from specialization, as opposed to diversification. While the majority of the world's largest companies continue to provide multiple services to numerous markets, they now purchase many components and goods from smaller companies that serve one particular niche. As the global marketplace continues to develop, women entrepreneurs in MSEs provide an effective tool for economic growth through participation in global supply chains (World Bank [14]).

UNIDO [13] added that a characteristic of women entrepreneurs in MSEs is that they produce predominantly for the domestic market, drawing in general on national resources; the structural shift from the former large state-owned enterprises to women entrepreneurs in MSEs will increase the number of owners, a group that represents greater responsibility and commitment than in the former centrally planned economies; an increased number of women entrepreneurs in MSEs will bring more flexibility to society and the economy and might facilitate technological innovation, as well as provide significant opportunities for the development of new ideas and skills; women entrepreneurs in MSEs use and develop predominantly domestic technologies and skills; New business development is a key factor for the success of regional reconversion where conventional heavy industries will have to phased out or be reconstructed (especially in the field of metallurgy, coalmining, heavy military equipment, etc.

\subsection{Objectives of the Study}

Generally, the study is designed to assess the major factors affecting the performance of women entrepreneurs in MSEs and the challenges they face in starting and running their own business in Polsara block of Ganjam district. Specifically, it is intended to assess:

1. The major characteristics of women entrepreneurs in MSEs and their enterprises.

2. The key factors that affect the performance of women entrepreneurs in MSEs.

\section{RESEARCH METHODOLOGY}

A sample of 150 women entrepreneurs was taken for the study using stratified and simple random sampling. In the process of answering the basic questions, a questionnaire that include demographic profiles, characteristics of women entrepreneurs and their enterprises and factors that affect the performance of women entrepreneurs in MSEs was designed. After the data has been collected, it was analyzed using SPSS by applying factor analysis. The data collection period was three months.

Most of the women entrepreneurs (54\%) belonged to the age group of 36 and above followed by the age groups of $26-35(28 \%)$ and $16-25(18 \%)$ in that order. Hisrich et al. [15] described the typical women entrepreneur to be about 35 years of age when she starts her first business venture. It appears women think of business idea in their thirties due to economic pressure/demand and more leisure time as their children are growing. Half $(51 \%)$ of the women interviewed, belonged to the low income level. $38 \%$ of them belonged to the middle class and 11 per cent belonged to the high income strata respectively. 
Table 1. Socio-demographic-economic profile

\begin{tabular}{|c|c|c|}
\hline \multirow[t]{2}{*}{$\begin{array}{l}\text { Socio-demographic } \\
\text { characteristics }\end{array}$} & \multirow{2}{*}{$\begin{array}{l}\text { Respondents } \\
\text { (N) } \\
n\end{array}$} & \multirow{2}{*}{$\begin{array}{l}150 \\
\%\end{array}$} \\
\hline & & \\
\hline \multicolumn{3}{|l|}{ Aqe } \\
\hline $16-25$ years & 27 & 18 \\
\hline $26-35$ years & 42 & 28 \\
\hline $\begin{array}{l}36 \text { and above years } \\
\text { Education }\end{array}$ & 81 & 54 \\
\hline Illiterates & 27 & 18 \\
\hline Less than 10th & 75 & 50 \\
\hline 10th & 21 & 14 \\
\hline 12th & 9 & 6 \\
\hline $\begin{array}{l}\text { Graduate and above } \\
\text { Marital status }\end{array}$ & Marital status & 12 \\
\hline Unmarried & 12 & 8 \\
\hline Married & 114 & 76 \\
\hline Widow/Widower & 15 & 10 \\
\hline Divorcee & 9 & 6 \\
\hline \multicolumn{3}{|l|}{ No. of children } \\
\hline None & 27 & 18 \\
\hline 1 & 18 & 12 \\
\hline 2 & 54 & 36 \\
\hline 3 & 30 & 20 \\
\hline 4 & 12 & 8 \\
\hline $\begin{array}{l}5 \text { and above } \\
\text { Income }\end{array}$ & 9 & 6 \\
\hline Rs. $500-2500$ & 75 & 50 \\
\hline Rs. $2501-5000$ & 57 & 38 \\
\hline Rs. $5001-7000$ & 18 & 12 \\
\hline
\end{tabular}

Educational status does not influence women in seeking entrepreneurship. This trend may leads to less realization of the need for appropriate preentrepreneurial interventions. Majority $(76 \%)$ of the women entrepreneurs were married and only low per cent of them were unmarried $(8 \%)$, widows (10\%) and divorces/separated (6\%). Married were experiencing freedom and receiving support directly and/ or indirectly to start and manage their enterprises. Further parents were expressing that economic independence through entrepreneurship is a barrier in fixing their marriage alliances. Single women households experiencing several problems like low/no support from both family as well as financial agencies.

Majority $(60 \%)$ of the respondents had fewer than two children, which included $18 \%$ who had no children, $12 \%$ were single parent, and $36 \%$ of the women entrepreneurs had two children. Only $40 \%$ of women entrepreneurs had more than two children. It is clear from the data that more women with small families enter entrepreneurship compared to those with large families. It is also expressed that fewer number of children means less responsibility and more free time which must be a facilitating factor for women to take up entrepreneurship.

\subsection{Characteristics of Women Entrepreneurs in MSEs and Women Owned Enterprises}

There are a number of distinct criteria that makes women entrepreneurs and their enterprises different from that of men entrepreneurs even though there are common elements. The following table shows the characteristics of respondents by sector they are working on, the number of employees working in the enterprise, legal ownership status of the business, reasons to start own business, who initiates the business idea, source of skill for starting the enterprise, source of starting fund and access to land.

\subsection{Sector}

The sectors in which women entrepreneurs are working in is depicted in the Table 2.

Table 2. Sectors respondents engaged in

\begin{tabular}{lll}
\hline Sector & Number & Percent \\
\hline Trade & 6 & 4 \\
Production & 78 & 52 \\
Services & 12 & 8 \\
Handcrafts & 54 & 36 \\
Total & & 100 \\
\hline
\end{tabular}

It is clearly seen from Table 2 that majority of the respondents $(52 \%)$ are engaged in the production sector. The service sector accounts $8 \%$ of the respondents. The hand crafts and trade take the remaining $36 \%$ and $4 \%$ respectively.

\subsection{Number of Employees in the Enterprise}

Women entrepreneurs in MSEs provide a large numbers of employment opportunities to the society. The Table 3 clearly shows the number of employees that women entrepreneurs in MSEs employ.

As you can see from the Table 3, majority of the respondents $(60 \%)$ hire more than 15 employees in their enterprise. But $24 \%$ respond that they employ less than 5 workers in their enterprise. 
The table also shows that $12 \%$ and $4 \%$ of the respondents hire from 11-15 employees and from 5-10 employees respectively.

Table 3. Number of employees hired

\begin{tabular}{lll}
\hline Number of employees & Number & Percent \\
\hline Less than 5 & 36 & 24 \\
$5-10$ & 6 & 4 \\
$11-15$ & 18 & 12 \\
More than 15 & 90 & 60 \\
Total & & 100 \\
\hline
\end{tabular}

3.4 Legal Ownership Status of the Establishment

Enterprises are created having different legal ownership statuses such as Sole ownership, Joint ownership, Family business, Cooperative and others (Hisrich $[7,8]$ ). The following Table 4 shows the respondents legal ownership status.

Table 4. Legal ownership of the enterprise

\begin{tabular}{lll}
\hline Legal ownership & Number & Percent \\
\hline Sole ownership & 3 & 2 \\
Joint ownership & 24 & 16 \\
Family business & 12 & 8 \\
Cooperative societies & 111 & 74 \\
Total & & 100 \\
\hline
\end{tabular}

As one can see from the Table 4, majority of the respondents $(74 \%)$ establish their enterprise in the form of cooperatives followed by joint ownership (16).The least number of respondents have a legal ownership of sole proprietorship business (2\%).

\subsection{Reasons to Start Own Business}

The motivators to establish own business are many in number and vary from individual to individual. The Table 5 shows the reasons that women entrepreneurs in MSEs are motivated to start their own enterprises.

Table 5 vividly shows that most of the respondent entrepreneurs (56\%) establish their own business for the reason that they have no other alternatives for income. $24 \%$ of the respondents start their own business since they want to be independent or have autonomy. Only $2 \%$ of the respondents establish their own business because they believe that it requires a small investment.
Table 5. Reason to start own business

\begin{tabular}{lll}
\hline Reasons to start & Number & Percent \\
\hline Family Tradition & 15 & 10 \\
$\begin{array}{l}\text { Independency/ } \\
\text { autonomous }\end{array}$ & 36 & 24 \\
$\begin{array}{l}\text { High Income } \\
\begin{array}{l}\text { Small Investment is } \\
\text { Required }\end{array}\end{array}$ & 9 & 6 \\
$\begin{array}{l}\text { No Other Alternative } \\
\text { for Income }\end{array}$ & 84 & 56 \\
$\begin{array}{l}\text { Successful Career } \\
\text { Total }\end{array}$ & 3 & 2 \\
\hline
\end{tabular}

\subsection{Initiation of the Business}

It is common that some start their own business with their own initiation and some others establish enterprises with family or friends as a partner. The Table 6 shows the initiators of women entrepreneurs to start own business.

The Table 6 clearly depicted that majority of the respondents $(58 \%)$ start enterprises with their own initiation. Similarly, $22 \%$ of the respondents start businesses with their family. It is only $3 \%$ of the entrepreneurs establish business with an initiation of a friend /partner.

Table 6. Initiation of the business

\begin{tabular}{lll}
\hline $\begin{array}{l}\text { Initiation of the } \\
\text { business }\end{array}$ & Number & Percent \\
\hline Myself Alone & 87 & 58 \\
With the Family & 33 & 22 \\
With a friend/ partner & 3 & 2 \\
Other & 27 & 18 \\
Total & & 100 \\
\hline
\end{tabular}

\subsection{Source of Skill for Running Your Enterprise}

In running any business, it is logical that the necessary skills are required. These skills can be acquired from different sources. The Table 7 shows the respondents source of skills to run their enterprises.

It is also indicated in the Table 7 that $64 \%$ of the respondents acquire the necessary skill for their business from formal trainings. Moreover, $20 \%$ of the entrepreneurs acquire their skills from their family. Only $8 \%$ of the respondent entrepreneurs acquire the skill from friends. 
Table 7. Source of skill for running your enterprise

\begin{tabular}{lll}
\hline Source of Skill & Number & Percent \\
\hline Through formal & 96 & 64 \\
training & & \\
From past experience & 12 & 8 \\
From family & 30 & 20 \\
From friends & 12 & 8 \\
Total & & 100 \\
\hline
\end{tabular}

\subsection{Source of Start-up Funding}

Starting own business requires a starting capital rather the mere existence of ideas. The following shows the main sources of start-up fund.

The Table 8 shows that majority of the respondents $(64 \%)$ use micro finance institutions as the main source of start-up funding in financing their enterprises. It is also clear that $6 \%$ of the entrepreneurs use previous work experience as their main source of start-up funding. The Table 8 shows that $2 \%$ of the entrepreneurs finance their business borrowing from relatives/friends/money lenders. Women entrepreneurs in MSEs now-a-days have started approaching banks and NGOs as a source of financing their business.

Table 8. Source of start-up funding

\begin{tabular}{|c|c|c|}
\hline $\begin{array}{l}\text { Source of start-up } \\
\text { funding }\end{array}$ & Number & Percent \\
\hline $\begin{array}{l}\text { Previous Work } \\
\text { Experience }\end{array}$ & 9 & 6 \\
\hline $\begin{array}{l}\text { Borrowed from friends/ } \\
\text { relatives/ money lenders }\end{array}$ & 3 & 2 \\
\hline $\begin{array}{l}\text { Micro-finance } \\
\text { Institutions }\end{array}$ & 96 & 64 \\
\hline $\begin{array}{l}\text { Assistant from friends/ } \\
\text { relatives }\end{array}$ & 3 & 2 \\
\hline Inheritance & 6 & 4 \\
\hline Borrowed from Bank & 6 & 4 \\
\hline NGOs & 18 & 12 \\
\hline Network/ Contacts & 9 & 6 \\
\hline Total & & 100 \\
\hline
\end{tabular}

\subsection{Challenges for Female Entrepreneurs}

Female respondents in general face specific challenges. The Table 9 shows some of the challenges that women entrepreneurs normally face.

In particular, family and household responsibilities are perceived as limiting factors. The second main constraint is lack of management experience. Limited access to networking opportunities was also specifically mentioned as a constraint applying more often to female entrepreneurs.

\section{Table 9. Challenges for female entrepreneurs}

\begin{tabular}{lll}
\hline $\begin{array}{l}\text { Challenges for female } \\
\text { entrepreneurs }\end{array}$ & Number & Percent \\
\hline $\begin{array}{l}\text { Lack of Management } \\
\text { Experience }\end{array}$ & 21 & 14 \\
Access to Finance & 9 & 6 \\
Access to Technology & 72 & 48 \\
$\begin{array}{l}\text { Access to Networking } \\
\text { Opportunities }\end{array}$ & 12 & 8 \\
Governmental Support & 6 & 4 \\
Access to Land & 9 & 6 \\
Gaining Acceptance & 12 & 8 \\
Inadequate access to & 9 & 6 \\
training & & 100 \\
Total & & \\
\hline
\end{tabular}

IBM SPSS 20 (Statistical Package for the Social Sciences) has been used for data analysis. The statistical tool used for this research work is factor analysis which has been elaborated here: Factor analysis is a statistical method used to describe variability among observed, correlated variables in terms of a potentially lower number of unobserved variables called factors. Factor analysis is commonly used in the fields of psychology and education and is considered the method of choice for interpreting self-reporting questionnaires. It is a multivariate statistical procedure that has the following uses: Firstly, factor analysis reduces a large number of variables into a smaller set of variables (also referred to as factors). Secondly, it establishes underlying dimensions between measured variables and latent constructs, thereby allowing the formation and refinement of theory. Thirdly, it provides construct validity evidence of selfreporting scales.

\subsection{Factors Affecting Women Entre- preneur's Performance in MSEs}

There are a number of factors that affect women entrepreneurs in MSEs associated with different factors.

The statistical tool used for this research work is factor analysis which has been elaborated here. Factor analysis is a statistical method used to describe variability among observed, correlated variables in terms of a potentially lower number of unobserved variables called factors. Factor analysis is commonly used in the fields of 
psychology and education and is considered the method of choice for interpreting self-reporting questionnaires.

Exploratory factor analysis was used to find out the factors that affect women entrepreneur's performance in MSEs. Cronbach's alpha is a measure of internal consistency, that is, how closely related a set of items are as a group. Cronbach's alpha is not a statistical test-it is a coefficient or reliability i.e., consistency. 20 numbers of items have been inducted to scale and test the reliability. The Cronbach's Alpha value is 0.787 . The KMO measures the sampling adequacy which should be greater than 0.5 for a satisfactory factor analysis to proceed. Looking at the Table 10, the KMO measure is 0.787 . Bartlett's test is another indication of the strength of the relationship among variables. This tests the null hypothesis that the correlation matrix is an identity matrix. From the same table we can see that the Bartlett's test of sphericity is significant. That is, its associated probability is less than 0.05 .

Table 10. KMO and Barlett's test of Sphericity

\begin{tabular}{|c|c|c|}
\hline \multicolumn{3}{|c|}{ KMO and Bartlett's test } \\
\hline $\begin{array}{l}\text { Kaiser-Meyer- } \\
\text { Sampling Ade }\end{array}$ & $\begin{array}{l}\text { lkin Measure of } \\
\text { uacy. }\end{array}$ & .787 \\
\hline $\begin{array}{l}\text { Bartlett's Test } \\
\text { of Sphericity }\end{array}$ & $\begin{array}{l}\text { Approx. Chi-square } \\
\text { df } \\
\text { Sig. }\end{array}$ & $\begin{array}{l}1905.911 \\
190 \\
.000\end{array}$ \\
\hline
\end{tabular}

Eigenvalue actually reflects the number of extracted factors whose sum should be equal to number of items which are subjected to factor analysis. The next item shows all the factors extractable from the analysis along with their eigenvalues.

The Eigenvalue table has been divided into three sub-sections, i.e. Initial Eigen Values, Extracted Sums of Squared Loadings and Rotation of Sums of Squared Loadings. For analysis and interpretation purpose we are only concerned with Extracted Sums of Squared Loadings. The total variance explained in Table 11 shows all the factors extractable from the analysis along with their eigen values, the percent of variance attributable to each other, and the cumulative variance of the factor and the previous factors. Here one should note that notice that the first factor accounts for $27.775 \%$ of the variance, the second $24.723 \%$, the third $7.478 \%$, the fourth one $5.740 \%$ and the fifth $5.135 \%$. All the remaining factors are not significant (Table 11).
From the Table 11, 5 factors have been extracted.

The idea of rotation is to reduce the number of factors on which the variables under investigation have high loadings. Rotation does not actually change anything but makes the interpretation of the analysis easier. Rotated component matrix provides sufficient evidence that all the variables can be segregated into six factors. Table 12 depicts the derived factors which are explained as follows.

After deducting the dimensions, the five factors which have been extracted are narrated hereby.

F1: While observing the results, variables like family welfare and moral support of family have loadings of 0.761 and 0.792 on factor F1 respectively. Therefore, this factor can be interpreted as "social factors". This factor is by far the most important one explaining $19.031 \%$ of the total variance.

F2: As it is clear from Table 12, statements like urge for learning, not afraid of business risk, do not get discouraged easily and high self esteem have loadings of $0.754,0.799,0.771$ and 0.588 represented by factor F2. It accounts for $18.399 \%$ of the total variance and has been named as "psychological factors".

F3: Table 12 indicates three statements, namely, government support, support of financial agencies and awareness about loan scheme has the loadings of $0.584,0.556$ and 0.761 . The factor F3 has been interpreted and named as "financial factors". This factor estimated to explain $15.471 \%$ of the total variance.

F4: The pattern of factor loading for interpreting factor 4 variables availability of raw material, demand for the product, infrastructure, warehousing facilities, power supply and skilled workforce has the loadings of $0.793,0.869$, $0.840,0.673,0.801$ and 0.851 . So, this variable comes under the heading of "work-related factors" and it is explaining $11.791 \%$ of total variance.

F5: The pattern of factor loading for interpreting factor 5 variables like self confidence, determination, innovative instincts, profitability of the business and achieve recognition in society has the loadings of $0.641,0.602,0.751,0.833$ and 0.816 , so; this variable comes under the heading of "entrepreneurial orientation factors". 


\section{FINDINGS OF THE STUDY}

There are few findings which have been extracted while analyzing the data. Kaiser-Meyer-Olkin measure of the sample adequacy is 0.787 which is above 0.5 required to apply the factor analysis. The review of this study found that there are five dissimilar components that can be drawn, which are social factors, psychological factors, financial factors, workrelated factors and entrepreneurial orientation factors.

In the recent era, the Indian women entrepreneurs are eager to do the business. Women have been taking interest in income generating activities through entrepreneurship. From the study it was found that $52 \%$ women respondents are engaged in production sector. More than $60 \%$ women respondents hire more than 15 employees. Majority of women comprising of $74 \%$ establish their enterprise in the form of cooperatives and $64 \%$ of the respondents seek micro-finance institutions as the main source of start - up funding in financing their enterprises. Access to technology is a major hurdle among the respondents.

The study further proves the relationship between psychological factors and women entrepreneurs orientation as it plays an important role in the orientation of women entrepreneurs because need to achieve power and affiliation are all reflected through psychological characteristics (McClelland [16]). If the women entrepreneurs are ready to learn the new techniques only then they can implement new innovations as they are seldom afraid of failure. Psychologically they have the courage to face the failures and remain in the business, which is reflected in this study.

Further, the study revealed that social support affect orientation of women entrepreneurs that is consistent with the results of the study by Pandey and Nair [17]. Helpful spouse is a source of motivation for women entrepreneurs as positive moral support encourages them to face the world more boldly. Further, this phenomenon is strengthened if family and society also motivates and support them. Previous literature (Ganesan et al. [18]; Nigam \& Sharma [19]) hints at work and worker-related problems but does not hold true here. The study reflects that they are also willing to take a business risk, which reflects their level of orientation for their business. It is concluded that women entrepreneurs have come of the age and they know how to tackle the work-related problems. It further reflects their confidence in running the business.

\section{CONCLUSION}

The results of the study show that women entrepreneurs faced a number of problems. The following suggestions are recommended to overcome the problems:

- Banks and financial institutions must come forward to support and motivate them to start the units.

- Financial help should be provided to women entrepreneurs by government as well as non-government financial agencies as it removes their difficulty in procuring loans.

- Sources of power supply should be raised for women entrepreneurs. The power supply should be regular in general for the ventures being run by women entrepreneurs in particular. The government should provide power at low rate and other facilities related with electricity to those units, which are started and operated by women entrepreneurs.

- Women entrepreneurs should be provided with special training and development programs for developing their innovative instincts.

\section{COMPETING INTERESTS}

Authors have declared that no competing interests exist.

\section{REFERENCES}

1. Ahl $\mathrm{H}$. Why research on women entrepreneurs needs new directions. In: Entrepreneurship Theory and Practice. 2006;30(5):595-621.

2. DeTienne D, Chandler G. The role of gender in opportunity identification. En: Entrepreneurship Theory and Practice. 2007;31(3):365-386.

3. Green P, et al. Women entrepreneurs: Moving front and center: An overview of research and theory. White Paper: United States Association for small business and Entrepreneurship; 2003.

Available:http://www.cofc.edu/entrepreneur consortium/resources/research women.ph p 
4. Samiti V. A research study on entrepreneurial challenges for SC Persons in India. New Delhi: Planning Commission Government of India Yojana Bhawan; 2006.

5. Tan J, Young E. Entrepreneurial infrastructure in Singapore: Developing a model and mapping participation. Journal of Entrepreneurship. 2000;9:1

6. Gemechis Tefera. Attitude of college students towards entrepreneurship: A case study of Addis Ababa University and Rift Valley University College. Addis Ababa, Ethiopia. Unpublished Thesis; 2007.

7. Hisrich RD. Entrepreneurship.7th Edition, Boston: McGraw Hill; 2005.

(Retrieved on 15-5-10)

Available:http://www.csb.uncw.edu/people/ rowej/classes/mba533old/MBA533 001 Class 6 Student.pdf

8. Hisrich RD. Entrepreneurship: New Venture creation. $5^{\text {th }}$ edition. Tata Mc Graw Hill, New Delhi; 2005.

9. ILO. Development Cooperation Ireland (2009). Women's entrepreneurship development: Capacity building guide. ILO-International Labour Organisation; Development Cooperation Ireland; 2009.

10. ILO. Vulnerability and young women Entrepreneurs: A case study of Ethiopian Informal Economy. Geneva: International Labor Organization; 2006.

(Retrieved on 16-5-10)

Available:http://www.cartierwomensinitiativ e.com/docs/Ethiopian women entreprene urs ILO.pdf
11. ILO. Women entrepreneurs in Kenya. Factors affecting Women entrepreneurs in micro and small enterprises in Kenya. Geneva. International Labor Organization; 2008.

12. Langowitz N, Minniti $M$. The entrepreneurial propensity of women. En: Entrepreneurship Theory and Practice. 2007;31(3):341-364.

13. UNIDO. Women entrepreneurship development in selected African Countries. Working Paper No. 7. Legos; 2001.

14. World Bank. Importance of SMEs and the Role of Public Support in Promoting SME Development; 2003.

(Retrieved on 23-5-10)

Available:http://info.worldbank.org/etools/d ocs/library/49256/fan.pdf

15. Hisrich RD, Brush CG. The women entrepreneur: Characteristics, skills. Problems and Prescriptions for Success. The Art and Science of Entrepreneurship, Cambridge, Mass, Ballinger; 1986.

16. McClelland DC. The achieving society. Princeton, NJ: Van Nostrand; 1996.

17. Pandey A, Nair KRG. Characteristics of entrepreneurs: An empirical analysis. Journal of Entrepreneurship. 2006;15(1): 47-61.

18. Ganesan R, Kaur D, Maheswari RC. Women entrepreneurs: Problems and prospect. Journal of Entrepreneurship. 2002;11(1):75-93.

19. Nigam S, Sharma SK. Problems and prospects of women entrepreneurs in Agra. Indian Journal of Commerce. 1997; 2(1):243-248.

(C) 2017 Roy et al.; This is an Open Access article distributed under the terms of the Creative Commons Attribution License (http://creativecommons.org/licenses/by/4.0), which permits unrestricted use, distribution, and reproduction in any medium, provided the original work is properly cited. http://sciencedomain.org/review-history/19130 